\title{
Influence of geochemical and anthropogenic sources on rainwater chemical composition in two coastal sites impacted by the gas and oil industry in Campeche, Mexico
}

\author{
R. M. Cerón ${ }^{1}$, J. G. Cerón ${ }^{1} \&$ M. Muriel $^{2}$ \\ ${ }^{1}$ Chemistry Faculty, Autonomous University of Carmen, Mexico \\ ${ }^{2}$ Mexican Petroleum Institute, Marine Zone Direction, Mexico
}

\begin{abstract}
The purpose of this research was to study rainwater chemical composition to assess the impact of marine aerosol and anthropogenic emissions, using $\mathrm{Cl}^{-}$as a sea-salt aerosol tracer. Influence of different sources to excess of ions was detected by means of back air-mass trajectories. Fieldwork was done from July to November 2004, in two coastal sites, Carmen Island and San Antonio Cardenas in Campeche Gulf, Mexico. Rainwater samples were analyzed for $\mathrm{Na}^{+}, \mathrm{Mg}^{2+}, \mathrm{K}^{+}, \mathrm{Ca}^{2+}, \mathrm{Cl}^{-}, \mathrm{SO}_{4}{ }^{2-}, \mathrm{NO}_{3}{ }^{-}$and $\mathrm{NH}_{4}{ }^{+}$, the average concentrations are reported and the results discussed. The observed concentrations are compared with other works in the Caribbean Sea Region and are interpreted in terms of enrichment factors and meteorological conditions.
\end{abstract}

Keywords: rainwater chemistry, marine aerosol, coastal rainwater composition, Mexico.

\section{Introduction}

Background level is a useful tool when a diagnosis about the possible environmental impact caused in a specific zone is required, allowing to establish a comparison when reference laws or standards of non criteria pollutants are not available. Commonly, these values are established for remote areas with a minimal anthropogenic influence, by this way, it is possible to accomplish a diagnosis of impact caused by non criteria pollutants such as rainwater acidity, carbonyl compounds, and so on. In fact, research on precipitation chemical 
composition of probably impacted zones, allow us to identify, first if there is an acidity problem, and second, to identify the main sources contributing to this acidity, and then to understand the process of transformation, transport, dilution and deposition of air pollutants. Objectives are accomplished by means of correlation between elements, local meteorology and back air-mass trajectories. Therefore to assess the impact from geochemical sources (marine aerosol, volcanic activity, and crustal) on chemical composition of rainwater in a specific region, knowledge of the background levels of wet deposition is required.

An important feature of the environmental assessment studies is the identification of all possible sources (biogenic, geochemical, natural, and anthropogenic) and to determine their relative contribution to the mineralization of rainwater.

Nriagu and Pacina [15] reported that human activities have an important effect on global and regional cycles of most of trace elements, whereas Duce et al [8] established that geochemical sources also may have an important influence upon trace elements through the different steps integrating biogeochemical cycles of elements in a region.

For this reason, it is essential to discuss the origin of trace elements to identify main sources using tracers. A method commonly used by geochemists to relate an element in rainwater with its geochemical source, involves the use of a tracer derived from the specific reference source. Therefore, to assess the enrichment of an element relative to its source, it is necessary to define the excess (fraction with an origin different from reference source), in terms of enrichment factor (EF). The most important geochemical sources contributing to rainwater mineralization in coastal and marine sites, where volcanic activity is not present, are marine aerosol and crustal, where sodium and chloride; and aluminum, respectively, are the main tracers, and where the specific reference sources are sea water and particles of crustal or soil, respectively (Chester et al. [5]).

Chemical composition of sea water is expressed as the ratio between the concentration of the element and the concentration of chloride ion, and it has been reported elsewhere (Culkin and Cox, [7]; Morris and Riley, [13]). In coastal and marine sites, it is assumed that relative proportion of elements as $\mathrm{Na}^{+}, \mathrm{K}^{+}$, $\mathrm{Ca}^{2+}, \mathrm{Mg}^{2+}, \mathrm{Cl}^{-}$and $\mathrm{Br}^{-}$in rainwater presents similarity to that reported for sea water. However, in some coastal and marine sites, the ratios of these elements are different in a significant way from their ratio for sea water, in spite of, it is believed that sea-salt is the main source of these trace components.

To assess the significance of sea surface as a source of aerosols, commonly, enrichment factor (EF) is used as an effective tool. An EF approaching to unity suggests that the trace element is originated in sea-salt (no enriched elements), whereas an EF greater than unity, suggests that a significant portion of the trace element has origin in a source different than sea-salt (enriched elements).

However, in the most of urban and industrial sites, trace elements atmospheric concentrations such as sulfate, zinc, cadmium and lead are significantly greater than those expected from the dispersion process of marine and mineral (crust) aerosols. Human activities are the main cause of the 
enrichment of these elements, and often they are referred as enriched elements or excess, in this case, local or regional meteorology data are necessary to identify the main responsible sources. Therefore, the excess of a constituent in a rainwater sample represents an increase of the element upon the levels expected from sea water and crustal particles and allow us to infer by using meteorology data, the influence of another sources such as anthropogenic sources on chemical composition of rainwater.

There is a clear increase in the contribution of nitric and sulfuric acids to rain acidity in the Gulf of Mexico, as air mass move toward the west (Bravo et al, [2]). Parungo et al [16] reported enrichment factors for $\mathrm{SO}_{4}{ }^{2-}$ of 10 , and high levels of $\mathrm{NO}_{3}{ }^{-}$in the Gulf of Campeche. However, Muriel et al [14] concluded in according to meteorological conditions prevailing in the zone, that air pollutants released from offshore platforms for exploration and production of gas and oil, are transported and deposited on Tabasco coastline. On the other hand, Ahmed et al [1] report that petroleum facilities in the east coast of Arabian affect sulfate and nitrate levels in rainwater, where both, nitrate and sulfate contribute in equal proportion to the acidity.

The present paper reports ions measurements data of wet deposition for rainy season in 2004, in two locations: one in a semi-urban marine site (Carmen Island), and the other, in a coastal site presumably impacted by the gas and oil industry (San Antonio Cardenas), both located in Campeche State, Mexico.

\section{Experimental}

\subsection{Sampling sites description}

Development of petroleum industry has been accelerated in the last years, in the region of Atasta-San Antonio Cardenas located in Campeche State. In this region, there is a gas recompression plant, where sour gas from offshore platforms is sent to petrochemical facilities to be processed. This recompression plant has four flare burners that use sour gas as fuel, releasing pollutants to the atmosphere. These flare burners or vent system compose the safety system of the plant avoiding over-pressure in transport pipes.

Both sampling sites (Carmen Island and San Antonio Cardenas) are into the Natural Reserved Area named "Laguna de Terminos" (Figure 1). Carmen Island is surrounded by Laguna de Terminos, at $18^{\circ} 40^{\prime} \mathrm{N}$ latitude and $91^{\circ} 52^{\prime} \mathrm{W}$ longitude, $40 \mathrm{~km}$ away from San Antonio Cardenas and $30 \mathrm{~km}$ away from recompression plant of sour gas in Atasta.

San Antonio Cardenas is located in Atasta Peninsula at $18^{\circ} 37^{\prime} \mathrm{N}$ latitude and $92^{\circ} 13^{\prime} \mathrm{W}$ longitude, $40 \mathrm{~km}$ away from Carmen Island and $10 \mathrm{~km}$ away from recompression plant of sour gas in Atasta.

Pom-Atasta Lagoon system is $30 \mathrm{~km}$ away from Carmen Island, at $18^{\circ} 33^{\prime}$, $18^{\circ} 38^{\prime} \mathrm{N}$ latitude and $92^{\circ} 01^{\prime}, 92^{\circ} 14^{\prime} \mathrm{W}$ longitude.

Laguna de Terminos has a total surface of $705,016 \mathrm{Ha}$ and is located at $18^{\circ}$ $03^{\prime} 27^{\prime \prime}, 19^{\circ} 10^{\prime} 35^{\prime \prime} \mathrm{N}$ latitude and $92^{\circ} 28^{\prime} 38^{\prime \prime}, 91^{\circ} 03^{\prime} 16^{\prime \prime} \mathrm{W}$ longitude. 
Mean annual temperature in this region is of $27.2{ }^{\circ} \mathrm{C}$, with rains occurring along the summer. Mean annual pluvial precipitation is of $1500 \mathrm{~mm} / \mathrm{year}$, and prevailing winds blow from $\mathrm{NE}$ and $\mathrm{SE}$ almost all the year with average velocities of $1.4 \mathrm{~m} / \mathrm{sec}$.

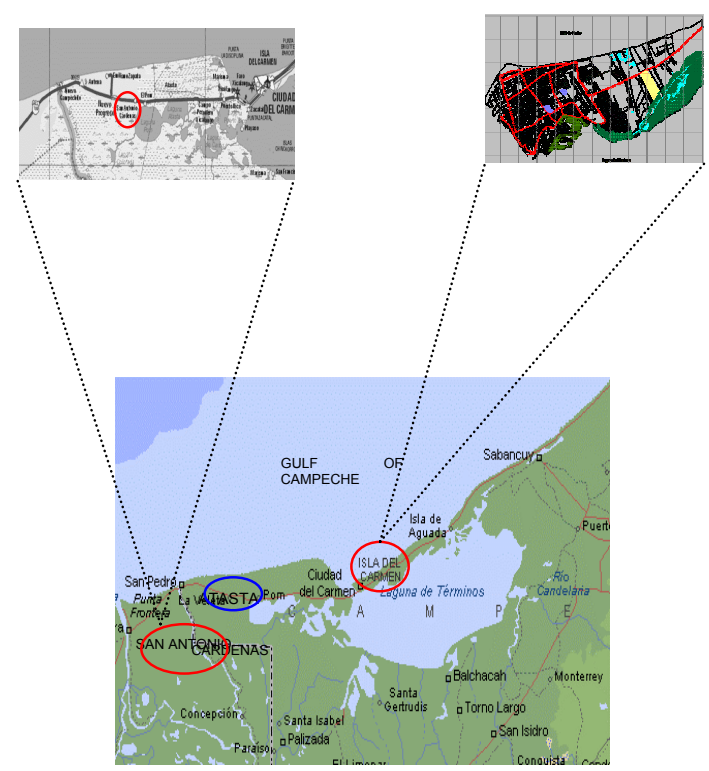

Figure 1: Map of the sampling sites location: San Antonio Cardenas and Carmen Island, identifying the location of the main emission source.

Campeche community, Natural Reserved Area committee and citizens of Atasta and San Antonio Cardenas have shown, since several years ago a constant concern about corrosion and its effects on their houses' roofs (mainly made of metallic sheets) and also about the effects caused on mangrove, and Pom-AtastaTerminos lagoon system; there is also a possible effect on fisheries because it is their main way of living.

\subsection{Sampling and analysis methodology}

Precipitation samples in both sites were collected using two automatic wet deposition collectors (Tisch, Inc) from 1 June to 30 October 2004. In San Antonio Cardenas, one collector was installed on the roof of a building in Technological University of Campeche. The other collector was installed on the roof of a building in Autonomous University of Carmen in Carmen Island. Trained technicians checked the samplers daily, typically between 8:00 and 10:00 h, local standard time, to retrieve, preserve with chloroform and refrigerate any collected precipitation. Samples with volume lesser than $250 \mathrm{ml}$ or polluted were discarded. 
Samples were sent weekly to Environmental Sciences Laboratory at UNACAR (Autonomous University of Carmen), where they were filtered (with a Kontes Ultra-Ware System, using a vacuum pump and Phenomenex membranes) and analyzed for $\mathrm{NH}_{4}^{+}, \mathrm{NO}_{3}^{-}, \mathrm{SO}_{4}{ }^{2-}, \mathrm{Cl}^{-}, \mathrm{Na}^{+}, \mathrm{K}^{+}, \mathrm{Ca}^{2+}$ and $\mathrm{Mg}^{2+}$.

Chloride, nitrate and sulfate were analyzed by non-suppressed chromatography with an Alltech chromatograph. For ammonium ion, an UVVisible spectrophotometer (Perkin Elmer) was used for its determination by a colorimetric method. $\mathrm{Na}^{+}, \mathrm{K}^{+}, \mathrm{Ca}^{2+}$ and $\mathrm{Mg}^{2+}$ were analyzed by flame atomic absorption spectrometry with a GBC atomic absorption spectrophotometer. $\mathrm{pH}$ and conductivity were also measured by using a potentiometer (HACH model EC10) and an YSI 3200 conductivity instrument. Ion balance and conductance percent differences of data were used for quality assurance. Also, field blanks were analyzed to guarantee the cleanness of the sampling material.

\subsection{Meteorology}

Yucatan Peninsula shows two climatic periods well defined, a dry season (From November to May) and a rainy season (From June to October). Sampling period occurred during summer and autumn; therefore it was not possible to assess seasonal patterns for each ionic component present in the rainwater of the two sampling sites. In both locations, surface winds data were not available. In this case, to identify the possible sources different from marine or mineral (crust) aerosol contributing to the excess levels or enrichment of ionic components in rainwater, back-air mass trajectories were used. The specific location of the site, the date and time of each precipitation event were registered; this data were provided to the NOAA Hybrid Single Particle Lagrangian Integrated Trajectory (HYSPLIT) model to generate 24-hour back trajectories. Examples of typical HYSPLIT trajectories are illustrated in Figure 2.

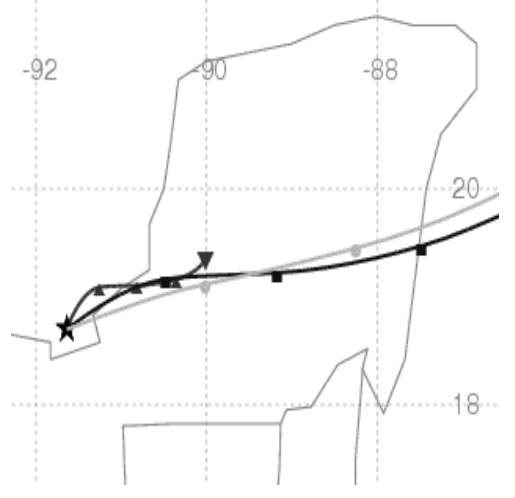

a)

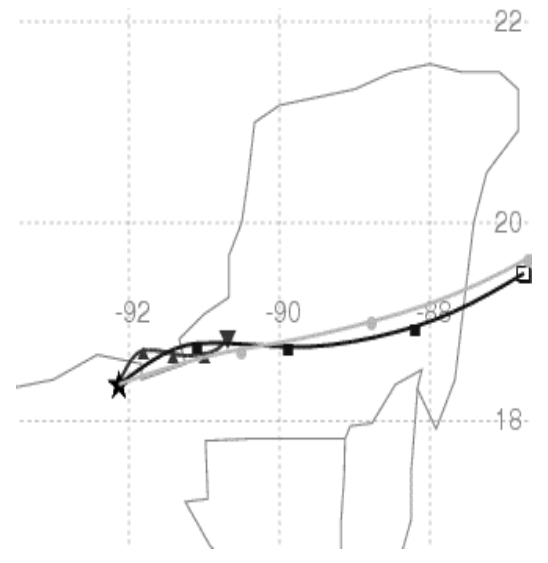

h)

Figure 2: Illustration of 24-hour air mass back trajectories used to identify the main pollution sources for two sampling sites: a) Carmen Island and b) San Antonio Cardenas. 
From figure 2, it can be observed that in both sites, prevailing winds during sampling period had an east component, mainly NE. San Antonio Cardenas was influenced by local anthropogenic sources located at NE from sampling site (Sour gas recompression plant), whereas Carmen Island was under the influence of maritime air and any significant anthropogenic influence was not identified.

\section{Results and discussion}

Ionic abundance obtained in San Antonio Cardenas and Carmen Island is presented in Table 1.

Table 1: $\quad$ Ionic abundance obtained in San Antonio Cardenas and Carmen Island.

\begin{tabular}{|c|c|c|}
\hline Elements & San Antonio Cárdenas & Carmen Island \\
\hline Cations & $\begin{array}{c}\mathrm{Na}^{+}>\mathrm{Ca}^{2+}>\mathrm{K}^{+}>\mathrm{Mg}^{2+}>\mathrm{NH}_{4}{ }^{+}> \\
\mathrm{H}^{+}\end{array}$ & $\begin{array}{c}\mathrm{Na}^{+}>\mathrm{Ca}^{2+}>\mathrm{Mg}^{2+}>\mathrm{K}^{+}>\mathrm{NH}_{4}{ }^{+} \\
>\mathrm{H}^{+}\end{array}$ \\
\hline Anions & $\mathrm{SO}_{4}{ }^{2-}>\mathrm{Cl}^{-}>\mathrm{NO}_{3}{ }^{-}$ & $\mathrm{Cl}^{-}>\mathrm{SO}_{4}{ }^{2-}>\mathrm{NO}_{3}{ }^{-}$ \\
\hline
\end{tabular}

The most abundant cations in both sites were $\mathrm{Na}^{+}$and $\mathrm{Ca}^{2+}$, probably due to influence of marine aerosol and crust (because of calcareous soils are abundant in Yucatan Peninsula). Agricultural practices are not present in any of two sites, for this reason $\mathrm{NH}_{4}^{+}$levels were very low. The most abundant anions in two locations were $\mathrm{Cl}^{-}$due to influence of sea-salt aerosol, and $\mathrm{SO}_{4}{ }^{2-}$, these high sulfate levels suggests there is influence of sources different from marine aerosol, mainly in San Antonio Cardenas. Table 2 shows the volume-weighted mean concentrations (VWM) for all collected samples in both sites.

Table 2: Volume-weighted mean concentrations in $\mathrm{mg} \mathrm{l}^{-1}$ for wet precipitation collected in San Antonio Cardenas and Carmen Island.

\begin{tabular}{|c|c|c|c|c|c|c|c|c|}
\hline $\begin{array}{c}\text { Sampling } \\
\text { site }\end{array}$ & $\mathrm{Na}^{+}$ & $\mathrm{K}^{+}$ & $\mathrm{Ca}^{2+}$ & $\mathrm{Mg}^{2+}$ & $\mathrm{SO}_{4}^{2-}$ & $\mathrm{Cl}^{-}$ & $\mathrm{NO}_{3}^{-}$ & $\mathrm{NH}_{4}^{+}$ \\
\hline $\begin{array}{c}\text { San } \\
\text { Antonio } \\
\text { Cardenas } \\
\mathrm{N}=26\end{array}$ & 2.47 & 0.37 & 1.06 & 0.33 & 3.85 & 3.84 & 2.50 & 0.09 \\
\hline $\begin{array}{c}\text { Carmen } \\
\text { Island } \\
\mathrm{N}=26\end{array}$ & 3.06 & 0.31 & 0.98 & 0.37 & 1.98 & 5.06 & 0.90 & 0.11 \\
\hline
\end{tabular}

The rainwater chemical composition observed in both sampling sites $\left(\mathrm{Na}^{+}\right.$, $\mathrm{K}^{+}, \mathrm{Ca}^{2+}, \mathrm{Mg}^{2+}$, and $\mathrm{Cl}^{-}$, except for nitrate and sulfate) was similar to that observed in other coastal and marine sites in the Caribbean Sea by other researchers (Cerón et al [4]; Bravo et al [2]; Clark et al [6]; Eklund et al [9]; Hendry et al [11]; Mc Dowell et al [12]). 
Based on enrichment factors (EF) results, it can be conclude that $\mathrm{Na}^{+}, \mathrm{Mg}^{2+}$ and $\mathrm{Cl}^{-}$have an origin typically marine (EF close to 1 ), whereas $\mathrm{K}^{+}, \mathrm{Ca}^{2+}$ and $\mathrm{SO}_{4}{ }^{2-}$ are enriched elements and showed a significant excess $(\mathrm{EF}>1)$, signifying that other sources are contributing notably to their levels present in rainwater. Sea-salt aerosol contributed to $91 \%$ of $\mathrm{Na}^{+}$and $90 \%$ of $\mathrm{Mg}^{2+}$ in Carmen Island; and $86 \%$ of $\mathrm{Na}^{+}$and $79 \%$ of $\mathrm{Mg}^{2+}$ in San Antonio Cardenas, suggesting that the influence of marine aerosol is more limited in San Antonio Cardenas. Since chloride ion was taken as the basis for excess calculations, sea-salt contributed to $100 \%$ of $\mathrm{Cl}^{-}$in both locations.

Proportions of sea-salt for $\mathrm{K}^{+}, \mathrm{Ca}^{2+}$ and $\mathrm{SO}_{4}{ }^{2-}$ were lower in both sampling sites, contributing to $34 \%$ of $\mathrm{K}^{+}, 11 \%$ of $\mathrm{Ca}^{2+}$ and $36 \%$ of $\mathrm{SO}_{4}^{2-}$ for Carmen Island, and $21 \%$ of $\mathrm{K}^{+}, 7 \%$ of $\mathrm{Ca}^{2+}$ and $14 \%$ of $\mathrm{SO}_{4}{ }^{2-}$ for San Antonio Cardenas, respectively.

High sulfate levels in both sites are comparable to that found in sites with anthropogenic influence. The average excess sulfate concentration $\left(\mathrm{SO}_{4}{ }^{2-}\right)_{\mathrm{xs}}$ based on chloride was 69.1 and $26.43 \mu \mathrm{Eq} \mathrm{l}^{-1}$ for San Antonio Cardenas and Carmen Island, respectively. These values are almost seven and three times higher than $\left(\mathrm{SO}_{4}{ }^{2-}\right)_{\mathrm{xs}}$ background hemispheric value reported by Galloway et al [10] for marine remote sites $\left(10 \mu \mathrm{Eq} \mathrm{l^{-1 }}\right)$, and it can be observed that anthropogenic influence in San Antonio Cardenas is greater than that observed in Carmen Island.

High nitrate concentrations were found in both locations, 11.06 and $3.98 \mu \mathrm{Eq}$ $1^{-1}$ for San Antonio Cardenas and Carmen Island, respectively. These values exceeded the $\mathrm{NO}_{3}{ }^{-}$background hemispheric concentration proposed by Casimiro et al [3] for coastal and marine remote sites $\left(2.8 \mu \mathrm{Eq} \mathrm{l}^{-1}\right)$, mainly in San Antonio Cardenas, suggesting the direct influence of anthropogenic sources in this site.

On the other hand, low ammonium levels were found in both sampling sites, this means that local sources with a significant contribution were not available, since agricultural practices are not present.

Even in areas considered as free of pollution, $\mathrm{pH}$ value for natural rainwater is of 5.6 due to presence of $\mathrm{CO}_{2}$ that dissolved in water to produce carbonic acid, the main responsible of this value. When $\mathrm{pH}$ value ranged from 5 to 5.6 , it can be considered that rainwater has enough buffer capacity so it is not an impacted site; but, when $\mathrm{pH}$ value is less than 5 , there is an evident anthropogenic source contributing to the acidity of rainwater. $\mathrm{pH}$ values in this study varied from 3.01 to 6.27 in San Antonio Cardenas and from 2.98 to 6.91 in Carmen Island. Mean $\mathrm{pH}$ value for San Antonio Cardenas was 4.64 and for Carmen Island was 5.38, suggesting a direct influence anthropogenic over chemical composition of rainwater in San Antonio Cardenas, therefore, this site can be considered as an impacted site.

The contribution of strong acids to the acidity of rainwater was determined from equivalent $\left(\mathrm{SO}_{4}{ }^{2-}\right)_{\mathrm{xs}} / \mathrm{H}^{+}$and $\mathrm{NO}_{3}{ }^{-} / \mathrm{H}^{+}$ratios; in both sites, these ratios were greater than unity, signifying that both acids contributed to $\mathrm{pH}$ values observed, being $\left(\mathrm{SO}_{4}{ }^{2-}\right)_{\mathrm{xs}}$ who contributed in a greater proportion than nitrate, mainly in San Antonio Cardenas. 
Correlation coefficients were calculated using a Pearson's matrix, significant correlations $\left(r^{2}>|0.75|\right)$ for main ions present in rainwater at San Antonio Cardenas and Carmen Island are shown in Table 3.

Table 3: Correlation coefficients among main ions present in rainwater at San Antonio Cardenas and Carmen Island.

\begin{tabular}{|c|c|c|}
\hline Ion pairs & Carmen Island & San Antonio Cardenas \\
\hline$\left(\mathrm{K}^{+}\right)-\left(\mathrm{Ca}^{2+}\right)$ & $0.9423^{*}$ & $0.9805^{*}$ \\
\hline$\left(\mathrm{Na}^{+}\right)-\left(\mathrm{Cl}^{-}\right)$ & $0.9386^{*}$ & $0.9985^{*}$ \\
\hline$\left(\mathrm{Na}^{+}\right)-\left(\mathrm{Mg}^{2+}\right)$ & $0.9489^{*}$ & $0.8914^{*}$ \\
\hline$(\mathrm{pH})-\left(\mathrm{SO}_{4}{ }^{2-}\right)$ & $-0.9535^{*}$ & $-0.8450^{*}$ \\
\hline$\left(\mathrm{SO}_{4}{ }^{2-}\right)-\left(\mathrm{NO}_{3}{ }^{-}\right)$ & $0.9625^{*}$ & $0.8356^{*}$ \\
\hline$(\mathrm{pH})-\left(\mathrm{NH}_{4}^{+}\right)$ & $0.8863^{*}$ & $0.9081^{*}$ \\
\hline
\end{tabular}

* Significant at the 0.005 level.

In both sites, elements showed a common trend; $\mathrm{K}^{+}$and $\mathrm{Ca}^{2+}$ had significant correlation, indicating a common source, probably particles of calcareous soils (crustal). On the other hand, a high correlation between $\left(\mathrm{Na}^{+}\right)-\left(\mathrm{Cl}^{-}\right)$and $\left(\mathrm{Na}^{+}\right)$$\left(\mathrm{Mg}^{2+}\right)$ indicates a marine origin since these elements are typically marine. In both cases, the concentrations of $\mathrm{NO}_{3}{ }^{-}$and $\mathrm{SO}_{4}{ }^{2-}$ demonstrate significant correlations, indicating their relationship to common anthropogenic sources and transport processes. $\mathrm{pH}$ had a significant inverse correlation with $\mathrm{SO}_{4}{ }^{2-}$ for both sites, this represents that $\mathrm{SO}_{4}{ }^{2-}$ contributes in a great proportion to the acidity of rainwater; whereas $\mathrm{NH}_{4}{ }^{+}$is positively well correlated with $\mathrm{pH}$, indicating that it can play a significant role in neutralization process of strong acids.

\section{Conclusions.}

In this paper the results of one year rainwater chemistry study were presented for a coastal site and an island, both located at Campeche Coast in Mexico. Excepting $\mathrm{NO}_{3}{ }^{-}$and $\mathrm{SO}_{4}{ }^{2-}$, ionic concentrations are in agreement with reported values in the Caribbean Region (Cerón et al [4]; Bravo et al [2]; Clark et al [6]; Eklund et al [9]; Hendry et al [11]; McDowell et al [12]). Marine aerosol contributes in a great proportion to $\mathrm{Na}^{+}, \mathrm{Mg}^{2+}$ and $\mathrm{Cl}^{-}$in both sites, whereas $\mathrm{K}^{+}$ and $\mathrm{Ca}^{2+}$ showed enrichment and probably are derived from crust. On the other hand, $\mathrm{NO}_{3}{ }^{-}$and $\mathrm{SO}_{4}{ }^{2-}$ levels in both locations, exceeded background levels reported for coastal and marine remote sites, suggesting that sources different from sea-salt aerosol are contributing to the mineralization process of rainwater, being this contribution more significant in San Antonio Cardenas. An analysis of air mass back trajectories indicates that main source for these high levels of $\mathrm{NO}_{3}{ }^{-}$ and $\mathrm{SO}_{4}{ }^{2-}$ is the sour gas recompression plant located at NE from San Antonio Cardenas. Results of this study made possible an environmental diagnosis and it can be concluded that Carmen Island is not impacted, whereas San Antonio Cardenas showed a strong acidity in the rainwater and it is directly impacted 
from anthropogenic activities, specifically the sour gas recompression plant located $10 \mathrm{~km}$ at NE.

\section{References}

[1] Ahmed A.F.M; Singh R.P; Elmubarak A.H. Chemistry of Atmospheric Precipitation at the Western Arabian Gulf Coast. Atmospheric Environment 24 (A), 2927-2934. 1990.

[2] Bravo H. A; Saavedra M. I; Sánchez P. A; Torres R. J; Granada, L. M. Chemical Composition of Precipitation in a Mexican Maya Region. Atmospheric Environment 34 (B), 1197 - 1204. 2000.

[3] Casimiro A. P; Salgueiro M. L; Núñez, V. T. Seasonal and Air-mass Trajectory Effects on Rainwater Quality at the Southwestern European Border. Atmospheric Environment 25(A), 2259 - 2266. 1991.

[4] Cerón R. M. B; Padilla H. G; Belmont R. D; Torres M. C. B; García R. M; Báez A. P. Rainwater Chemical Composition at the End of the Midsummer Drought in the Caribbean Shore of the Yucatan Peninsula. Atmospheric Environment 36, 2367 - 2374. 2002.

[5] Chester R; Nimmo M; Murphy K.J.T; Nicholas E. Atmospheric trace metals transported to the western Mediterranean: data from a station on Cap Ferrat. In: Second EROS 2000 Workshop, Blanes, Spain, 6-9 February 1990. Water Pollution Research Reports 20, 597-612. 1990.

[6] Clark K.L; Nadkarni N.M; Schaefer D; Gholz, H.L. Cloud water and precipitation chemistry in a tropical montane forest, Monteverde, Costa Rica. Atmospheric Environment 32, 1595-1603. 1998.

[7] Culkin F. and Cox R.A. Sodium, Potassium, Magnesium, Calcium and Strontium in Sea Water. Deep Sea Research 13, 789-804. 1966.

[8] Duce R.A; Liss P.S; Merrill J.T; Atlas E.L; Buat-Menard P; Miller J.M; Prospero J.M; Arimoto R; Church T.M; Ellis W; Galloway J.N; Hansen L; Jickells T.D; Knap A.H; Reinhardt K.H; Schneider B; Soudine A; Tokos J.J; Tsunogai S; Wollast R; Zhou, M. The atmospheric input of trace species to the world ocean. Global biogeochemical cycles 5, 193259. 1991.

[9] Eklund T. J; McDowell W. H; Pringle C. M. Seasonal Variation of Tropical Precipitation Chemistry: La Selva, Costa Rica. Atmospheric Environment 31, 3903 - 3910. 1997.

[10] Galloway J.N; Likens G.E. Keene W.C; Miller J.M. The Composition of Precipitation in Remote Areas of the World. Journal of Geophysical Research 87, 8771-8776. 1982.

[11] Hendry C. D; Berish C. W; Edgerton E. S. Precipitation Chemistry at Turrialba, Costa Rica. Water Resources Research. 20, 1677 - 1684. 1984.

[12] McDowell W.H; Ginés S.C; Asbury C.E; Ramos P.C. Influence of seasalt aerosol and long range transport on precipitation chemistry at El Verde, Puerto Rico. Atmospheric Environment 24 (A), 2813-2821. 1990. 
[13] Morris A.W; and Riley J.P. The Bromide/chlorinity and Sulphate/chlorinity Ratio in Sea Water. Deep Sea Research 13, 699705. 1966.

[14] Muriel G.M; Mendoza A.A; Chávez, J.A. Assessment of the air quality in coastal and marine region of PEP. Contract F.00590. Mexican Petroleum Institute -PEMEX. 1998.

[15] Nriagu J.O; Pacina J.M. Quantitative assessment of worldwide contamination of air, water and soils by trace metals. Nature 333, 134139. 1988.

[16] Parungo F; Nagamoto C; Hoyt S; Bravo H. The Investigation of Air Quality and Acid Rain over the Gulf of México. Atmospheric Environment 24 (A), 109 - 123. 1990. 